\title{
FORMULASI SEDIAAN SABUN CAIR EKSTRAK ETANOL DAUN TURI (Sesbania grandiflora L.) DAN UJI ANTIJAMUR TERHADAP Candida albicans
}

\section{FORMULATION OF LIQUID SOAP PREPARATION OF HUMMINGBIRD (Sesbania grandiflora L.) LEAF ETHANOL EKSTRACT AND THE ANTIFUNGAL TEST OF Candida albicans}

\author{
Mariando N. Ering ${ }^{1)}$, Paulina V. Y. Yamlean ${ }^{1)}$, Irma Antasionasti ${ }^{1)}$ \\ ${ }^{1)}$ Program Studi Farmasi FMIPA UNSRAT Manado, 95115 \\ *e-mail : mariando.ering98@gmail.com
}

\begin{abstract}
The leaves of Hummingbird (Sesbania grandiflora L.) contain flavonoid compounds, saponins and tannins that are antifungal. This research aims to formulate liquid soap extracts of Hummingbird leaf ethanol and test the effectiveness of the antifungal preparations of the liquid soap of Hummingbird leaf ethanol with a concentration of 4\%, 6\%, 8\%, 10\% and 12\% of the fungus growth of Candida albicans. This research uses experimental methods. The formulation of this liquid soap of Hummingbird leaf ethanol is conducted organoleptic test, $\mathrm{pH}$, high foam, moisture content, free alkaline content, and type weights. Testing the effectiveness of antifungal to Candida albicans growth is done by diffusion method. Liquid soap preparations of Hummingbird leaf ethanol extract meet the standards set by SNI for organoleptic testing, pH test, Foam High test, water content test, free alkali rate test, and type weight test. Based on the anti-fungal testing of the preparation of a liquid soap extract of Hummingbird leaf ethanol to the fungus Candida albicans obtained the results of all preparations have a resistance to fungi and strong categorized.
\end{abstract}

Keywords: Hummingbird leaves, Liquid soap, Antifungal

\begin{abstract}
ABSTRAK
Daun Turi (Sesbania grandiflora L.) memiliki kandungan senyawa flavonoid, saponin dan tannin yang bersifat sebagai antijamur. Penelitian ini bertujuan untuk memformulasikan sabun cair ekstrak etanol daun Turi dan menguji efektivitas antijamur sediaan sabun cair ekstrak etanol daun Turi dengan konsentrasi 4\%, 6\%, 8\%, 10\% dan 12\% terhadap pertumbuhan jamur Candida albicans. Penelitian ini menggunakan metode eksperimental. Formulasi sediaan sabun cair ekstrak etanol daun Turi ini dilakukan pengujian organoleptik, $\mathrm{pH}$, tinggi busa, kadar air, kadar alkali bebas, dan bobot jenis. Pengujian efektivitas antijamur terhadap pertumbuhan Candida albicans dilakukan dengan metode difusi. Sediaan sabun cair ekstrak etanol daun turi memenuhi standar yang ditetapkan SNI pada pengujian organoleptik, uji pH, uji tinggi busa, uji kadar air, uji kadar alkali bebas, dan uji bobot jenis. Berdasarkan pengujian antijamur sediaan sabun cair ekstrak etanol daun Turi terhadap jamur Candida albicans didapatkan hasil semua sediaan memiliki daya hambat terhadap jamur dan dikategorikan kuat.
\end{abstract}

Kata Kunci: Daun Turi, Sabun Cair, Antijamur 


\section{PENDAHULUAN}

Infeksi Candida albicans pada manusia biasanya disebut kandidiasis. Kandidiasis dapat mengenai mukosa mulut, alat kelamin, kuku, kulit, bronki atau paru-paru. Penyakit ini ditemukan di seluruh dunia dan dapat menyerang semua umur baik laki-laki maupun perempuan. Berdasarkan beberapa kasus yang terjadi, penderita kandidiasis ini 70\% perempuan (Farizal dan Dewa, 2017). Penyakit infeksi masih menjadi masalah serius di Indonesia ditambah dengan semakin meluasnya resistensi mikroba terhadap obat-obat antibiotika yang tersedia. Hal tersebut mendorong pentingnya penggalian sumber obatobat antimikroba lain dari bahan alam. Tanaman obat diketahui potensial untuk dikembangkan lebih lanjut pada pengobatan infeksi, namun masih banyak yang belum dibuktikan bioaktivitasnya secara ilmiah (Astriani, 2011).

Oleh karena itu, perlu dilakukan pembuktian bioaktivasi senyawa yang berasal dari daun Turi dan efektif untuk menanggulangi infeksi kandidiasis. Tanaman Turi mengandung beberapa senyawa aktif yaitu tannin, flavonoid dan saponin yang dapat menghambat pertumbuhan bakteri Staphylococcus aureus dan Candida albicans (Ratna et al, 2016).

Sabun adalah suatu sediaan yang digunakan oleh masyarakat sebagai pembersih kulit. Berbagai jenis sabun yang beredar di pasaran dalam bentuk yang bervariasi seperti sabun cuci, sabun mandi, sabun tangan, sabun pembersih peralatan rumah tangga dalam bentuk krim, padatan atau batangan, bubuk dan cair. Sabun cair saat ini banyak diproduksi karena penggunaannya yang lebih praktis dan bentuk yang menarik dibanding bentuk sabun lain (Mutmainah dan Franyoto, 2015).

Di samping itu sabun dapat digunakan untuk mengobati penyakit, seperti mengobati penyakit kulit yang disebabkan oleh bakteri dan jamur. Sabun dapat digunakan sebagai obat yakni dengan membersihkan tubuh sehingga kemungkinan terserang penyakit akan berkurang.

\section{METODOLOGI PENELITIAN \\ Waktu dan Tempat Penelitian}

Penelitian ini akan dilaksanakan pada bulan November 2019-Februari 2020 di Laboratorium Farmasi Lanjut Program Studi Farmasi, Fakultas Matematika dan Ilmu Pengetahuan Alam, Universitas Sam Ratulangi.

\section{Bentuk Penelitian}

Penelitian ini ialah penelitian eksperimental laboratorium dengan membuat fomulasi sediaan sabun cair ekstrak etanol daun Turi (Sesbania grandiflora L.) dengan konsentrasi $4 \%, 6 \%, 8 \%, 10 \%$ dan $12 \%$.

\begin{abstract}
Alat dan Bahan
Alat

Alat yang akan digunakan dalam penelitian ini ialah alat-alat gelas (pyrex ${ }^{\circledR}$ Iwaki), $\mathrm{pH}$ meter (Emeltron), batang pengaduk, timbangan analitik (BB Adam), inkubator (Ecocell MMM Group), autoklaf (ALP), oven, blender (Philips), piknometer (pyrex ® Iwaki), jarum ose, pinset, mistar berskala, jangka sorong, alumunium foil (Klin Pak), toples, hot plate magnetic stirrer (Nesco Lab) dan ayakan.
\end{abstract}

\section{Bahan}

Bahan yang akan digunakan dalam penelitian ini ialah daun Turi (Sesbania grandiflora L.), isolat jamur Candida albicans, Minyak Zaitun, Kalium Hidroksida (KOH), Natrium Carboksil Metil Celulosa (Na-CMC), Sodium Lauryl Sulfate (SLS), Asam Stearat, Butyl Hidroksi Anisol (BHA), Indikator Fenolftelein, Pengaroma Rose, Alkohol 96\%, Potato Dextrose Agar (PDA), $\mathrm{BaCl}_{2} 2 \mathrm{H}_{2} \mathrm{O}, \mathrm{H}_{2} \mathrm{SO}_{4}, \mathrm{NaCl}, \mathrm{HCl}$, Betadin SC dan Aquadest. 


\section{Prosedur Penelitian}

Penyiapan dan Pengambilan Sampel

Pengambilan sampel daun Turi (Sesbania grandiflora L.) di Kelurahan Sagrat, Kecamatan Matuari, Kota Bitung. Sampel dipreparasi dan daun yang terkumpul dicuci bersih dengan air mengalir untuk menghilangkan pengotor. Pengeringan daun dilakukan dengan cara dianginanginkan di dalam ruangan selama 6 hari sampai daun kering. Daun kering kemudian diserbuk lalu diayak menggunakan ayakan tepung dan dilanjutkan dengan proses ekstrasi.

\section{Ekstrasi}

Proses ekstrasi serbuk daun Turi (Sesbania grandiflora L.) dibuat dengan cara maserasi. Serbuk daun Turi ditimbang sebanyak $500 \mathrm{~g}$ dan dimasukan dalam toples lalu ditambahkan pelarut etanol $96 \%$ sebanyak 2500 $\mathrm{mL}$ dan didiamkan selama 3 hari sambil sesekali diaduk. Setelah 3 hari, sampel yang direndam kemudian disaring dengan menggunakan kertas saring dan menghasilkan filtrat 1 dan debris 1 . Debris 1 yang ada kemudian direndam lagi (remaserasi) dengan pelarut yang sama selama 2 hari sambil sesekali diaduk. Setelah 2 hari, sampel disaring sehingga menghasilkan filtrat 2 dan debris 2 . Filtrat 1 dan 2 dicampurkan menjadi satu lalu dievaporasi di dalam oven pada suhu $40^{\circ} \mathrm{C}$ sehingga diperoleh ekstrak kental daun Turi.

\section{Formulasi Sabun Cair Ekstrak Etanol Daun Turi}

Tabel 1. Formula sabun cair ekstrak etanol daun Turi (Sesbania grandiflora L.)

\begin{tabular}{ccccccccc}
\hline \multirow{2}{*}{ Bahan } & \multirow{2}{*}{ Fungsi } & \multirow{2}{*}{ Satuan } & \multicolumn{7}{c}{ Konsentrasi } \\
\cline { 5 - 9 } & & & Basis & F1 & F2 & F3 & F4 & F5 \\
\hline $\begin{array}{c}\text { Ekstrak Etanol Daun } \\
\text { Turi }\end{array}$ & Zat Aktif & & & $4 \%$ & $6 \%$ & $8 \%$ & $10 \%$ & $12 \%$ \\
\hline Minyak Zaitun & Asam Lemak & $\mathrm{mL}$ & 15 & 15 & 15 & 15 & 15 & 15 \\
\hline KOH & Basa & $\mathrm{mL}$ & 8 & 8 & 8 & 8 & 8 & 8 \\
\hline Na-CMC & $\begin{array}{c}\text { Pengisi dan } \\
\text { Pengental }\end{array}$ & $\mathrm{g}$ & 0,5 & 0,5 & 0,5 & 0,5 & 0,5 & 0,5 \\
\hline SLS & Surfaktan & $\mathrm{g}$ & 0,5 & 0,5 & 0,5 & 0,5 & 0,5 & 0,5 \\
\hline Asam Stearat & Penetral & $\mathrm{g}$ & 0,25 & 0,25 & 0,25 & 0,25 & 0,25 & 0,25 \\
\hline BHA & Antioksidan & $\mathrm{g}$ & 0,5 & 0,5 & 0,5 & 0,5 & 0,5 & 0,5 \\
\hline Pengaroma Rose & Pengaroma & $\mathrm{mL}$ & 1 & 1 & 1 & 1 & 1 & 1 \\
\hline Aquades & Pelarut & $\mathrm{mL}$ & $\mathrm{ad} 50$ & $\mathrm{ad} 50$ & $\mathrm{ad} 50$ & $\mathrm{ad} 50$ & $\mathrm{ad} 50$ & $\mathrm{ad} 50$ \\
\hline
\end{tabular}

\section{Pembuatan Sabun Cair Ekstrak Etanol Daun Turi}

Semua bahan yang akan digunakan ditimbang terlebih dahulu sesuai dengan takaran yang dianjurkan. Dimasukkan minyak zaitun sebanyak $15 \mathrm{~mL}$ ke dalam gelas kimia, kemudian ditambahkan dengan kalium hidroksida 40\% sebanyak $8 \mathrm{~mL}$ sedikit demi sedikit sambil terus dipanaskan pada suhu $50^{\circ} \mathrm{C}$ hingga mendapatkan sabun pasta. Sabun pasta ditambahkan dengan kurang lebih $15 \mathrm{~mL}$ aquades, lalu dimasukkan natrium karboksil metal selulosa yang telah dikembangkan dalam aquades panas, diaduk hingga homogen. Kemudian ditambahkan asam stearat, diaduk hingga homogen. Ditambahkan sodium laurel sulfat, diiaduk hingga homogen. Ditambahkan butyl hidroksi anisol, lalu diaduk hingga homogen. Dimasukkan ekstrak etanol daun Turi, diaduk hingga homogen. Sabun cair ditambahkan dengan aquades hingga volumenya $100 \mathrm{~mL}$, dimasukkan ke dalam wadah bersih yang telah disiapkan. Pembuatan sabun cair ekstrak 
etanol daun Turi disesuaikan dengan masingmasing konsentrasi.

\section{HASIL DAN PEMBAHASAN}

Proses formulasi sediaan sabun cair ektrak daun Turi dibuat pertama dengan membuat basis sabun cair dari asam lemak dan basa kemudian ditambahkan zat tambahan dan zat aktif secara bertahap

Tabel 2. Hasil uji organoleptik

\begin{tabular}{cccc}
\hline Sediaan & Bentuk & Bau & Warna \\
\hline Basis Sabun Cair & Cair & Khas & Puth \\
\hline $\begin{array}{c}\text { Sabun cair } \\
\text { konsentrasi 4\% }\end{array}$ & Cair & Khas & Hijau \\
$\begin{array}{c}\text { Sabun cair } \\
\text { konsentrasi 6\% }\end{array}$ & Cair & Khas & Hijau \\
\hline $\begin{array}{c}\text { Sabun cair } \\
\text { konsentrasi 8\% }\end{array}$ & Cair & Khas & Hijau Tua \\
\hline $\begin{array}{c}\text { Sabun cair } \\
\text { konsentrasi 10\% }\end{array}$ & Cair & Khas & Hijau Tua \\
\hline $\begin{array}{c}\text { Sabun cair } \\
\text { konsentrasi 12\% }\end{array}$ & Cair & Khas & Hijau Tua \\
\hline
\end{tabular}

Uji organoleptik dilakukan dengan tujuan untuk melihat bentuk fisik dari sediaan sabun cair yang dibuat meliputi bentuk, warna dan bau. Bentuk dari sediaan sabun cair yang dibuat ialah berbentuk cair. Warna yang dihasilkan ialah warna hijau, dimana semakin tinggi konsentrasi maka akan semakin gelap karena dipengaruhi oleh konsentrasi ekstrak daun turi. Aroma yang dihasilkan ialah aroma khas, yaitu aroma antara pengaroma rose dan aroma alami dari ekstrak daun turi yang tercampur. Sediaan sabun cair ekstrak daun turi memenuhi standar yang ditetapkan SNI yaitu berbentuk cair, aroma dan warna khas.

Tabel 3. Hasil uji pH

\begin{tabular}{ccc}
\hline Sediaan & pH & Keterangan \\
\hline Basis Sabun Cair & 9,80 & Memenuhi syarat \\
\hline $\begin{array}{c}\text { Sabun cair } \\
\text { konsentrasi 4\% }\end{array}$ & 9,03 & Memenuhi syarat \\
\hline $\begin{array}{c}\text { Sabun cair } \\
\text { konsentrasi 6\% }\end{array}$ & 9,12 & Memenuhi syarat \\
\hline $\begin{array}{c}\text { Sabun cair } \\
\text { konsentrasi 8\% }\end{array}$ & 9,14 & Memenuhi syarat \\
\hline $\begin{array}{c}\text { Sabun cair } \\
\text { konsentrasi 10\% }\end{array}$ & 8,95 & Memenuhi syarat \\
\hline $\begin{array}{c}\text { Sabun cair } \\
\text { konsentrasi 12\% }\end{array}$ & 9,04 & Memenuhi syarat \\
\hline
\end{tabular}

Sediaan sabun cair harus melewati uji $\mathrm{pH}$, yang bertujuan untuk melihat nilai $\mathrm{pH}$ dari sediaan sabun cair. Nilai $\mathrm{pH}$ yang diperbolehkan untuk sediaan sabun cair menurut SNI antara 8-11. Hal ini penting dilakukan karena sabun cair akan bersentuhan langsung dengan kulit. Jika $\mathrm{pH}$ yang dimiliki oleh sediaan sabun cair tidak memenuhi standar, maka dapat menimbulkan masalah pada kulit. Kulit memiliki kapasitas ketahanan dan dapat dengan cepat beradaptasi terhadap produk yang memiliki pH 8.0-10.8 (Frost dan Horowitz, 1982). Berdasarkan hasil pengujian terhadap sediaan sabun cair ekstrak daun Turi, menunjukan bahwa nilai $\mathrm{pH}$ berada diantara 8-11. Sabun cair bersifat basa karena sabun cair merupakan garam alkali dari asam lemak. Maka sediaan sabun cair ektrak daun turi memenuhi standart dari SNI.

Tabel 4. Hasil uji tinggi busa

\begin{tabular}{ccc}
\hline Sediaan & $\begin{array}{c}\text { Tinggi busa } \\
(\mathbf{m m})\end{array}$ & Keterangan \\
\hline Basis Sabun Cair & 75 & $\begin{array}{c}\text { Memenuhi } \\
\text { syarat }\end{array}$ \\
\hline $\begin{array}{c}\text { Sabun cair } \\
\text { konsentrasi 4\% }\end{array}$ & 73 & $\begin{array}{c}\text { Memenuhi } \\
\text { syarat }\end{array}$ \\
\hline $\begin{array}{c}\text { Sabun cair } \\
\text { konsentrasi 6\% }\end{array}$ & 73 & $\begin{array}{c}\text { Memenuhi } \\
\text { syarat }\end{array}$ \\
\hline $\begin{array}{c}\text { Sabun cair } \\
\text { konsentrasi 8\% }\end{array}$ & 71 & $\begin{array}{c}\text { Memenuhi } \\
\text { syarat }\end{array}$ \\
\hline $\begin{array}{c}\text { Sabun cair } \\
\text { konsentrasi 10\% }\end{array}$ & 70 & $\begin{array}{c}\text { Memenuhi } \\
\text { syarat }\end{array}$ \\
\hline $\begin{array}{c}\text { Sabun cair } \\
\text { konsentrasi 12\% }\end{array}$ & 70 & $\begin{array}{c}\text { Memenuhi } \\
\text { syarat }\end{array}$ \\
\hline
\end{tabular}

Pengujian yang selanjutnya dilakukan ialah pengujian tinggi busa. Tujuan dari pengujian busa ialah untuk melihat daya busa dari sabun cair. Berdasarkan SNI, tinggi busa dari sediaan sabun cair harus berada diantara $13-220 \mathrm{~mm}$. Tinggi busa yang didapatkan pada pengujian, menunjukan nilai tinggi busa pada sediaan sabun cair berada diantara 70-75 mm, yang artinya masih memenuhi standar yang ditetapkan SNI. Jika busa yang dihasilkan terlalu banyak dapat mengakibatkan kulit teriritasi. Karena banyaknya busa menunjukan juga banyaknya SLS (Sodium Lauryl Sulfate) yang digunakan sebagai pembusa, dimana senyawa tersebut dapat mengiritasi kulit jika digunakan terlalu banyak dalam sabun. 
Tabel 5. Hasil uji kadar air

\begin{tabular}{ccc}
\hline Sediaan & Kadar air & Keterangan \\
\hline Basis Sabun Cair & $62,65 \%$ & $\begin{array}{c}\text { Tidak memenuhi } \\
\text { syarat }\end{array}$ \\
\hline $\begin{array}{c}\text { Sabun cair } \\
\text { konsentrasi 4\% }\end{array}$ & $59,83 \%$ & Memenuhi syarat \\
\hline $\begin{array}{c}\text { Sabun cair } \\
\text { konsentrasi 6\% }\end{array}$ & $58,57 \%$ & Memenuhi syarat \\
\hline $\begin{array}{c}\text { Sabun cair } \\
\text { konsentrasi 8\% }\end{array}$ & $58,48 \%$ & Memenuhi syarat \\
\hline $\begin{array}{c}\text { Sabun cair } \\
\text { konsentrasi 10\% }\end{array}$ & $54,96 \%$ & Memenuhi syarat \\
\hline $\begin{array}{c}\text { Sabun cair } \\
\text { konsentrasi 12\% }\end{array}$ & $51,05 \%$ & Memenuhi syarat \\
\hline
\end{tabular}

Selanjutnya dilakukan pengujian kadar air untuk mengetahui kandungan kadar air dalam sediaan sabun cair. Tujuan dari pengujian ini untuk mengukur kadar air dalam sediaan, dimana kadar air dapat menyebabkan mudahnya bakteri, kapang dan khamir untuk berkembang biak sehingga mempengaruhi perubahan terhadap sediaan. Kadar air maksimum untuk sediaan sabun cair harus $<60 \%$ sesuai yang telah ditetapkan oleh SNI. Hasil yang didapatkan menunjukan bahwa semua sediaan sabun cair memiliki kadar air berada di bawah $60 \%$ kecuali pada basis sabun cair yang memiliki kadar air di atas dari 60\%. Penyebab kadar air dari basis sabun cair lebih dari $60 \%$ disebabkan karena beberapa bahan bersifat higroskopis seperti SLS (Sodium Lauryl Sulfate) dan Na-CMC (Natrium Carboxy Methyl Cellulose.

Tabel 6. Hasil uji kadar alkali bebas

\begin{tabular}{ccc}
\hline Sediaan & $\begin{array}{c}\text { Kadar alkali } \\
\text { bebas }\end{array}$ & Keterangan \\
\hline Basis Sabun Cair & $0,046 \%$ & $\begin{array}{c}\text { Memenuhi } \\
\text { syarat }\end{array}$ \\
\hline $\begin{array}{c}\text { Sabun cair } \\
\text { konsentrasi 4\% }\end{array}$ & $0,046 \%$ & $\begin{array}{c}\text { Memenuhi } \\
\text { syarat }\end{array}$ \\
$\begin{array}{c}\text { Sabun cair } \\
\text { konsentrasi 6\% }\end{array}$ & $0,056 \%$ & $\begin{array}{c}\text { Memenuhi } \\
\text { syarat }\end{array}$ \\
\hline $\begin{array}{c}\text { Sabun cair } \\
\text { konsentrasi 8\% }\end{array}$ & $0,065 \%$ & $\begin{array}{c}\text { Memenuhi } \\
\text { syarat }\end{array}$ \\
\hline $\begin{array}{c}\text { Sabun cair } \\
\text { konsentrasi 10\% }\end{array}$ & $0,075 \%$ & $\begin{array}{c}\text { Memenuhi } \\
\text { syarat }\end{array}$ \\
$\begin{array}{c}\text { Sabun cair } \\
\text { konsentrasi 12\% }\end{array}$ & $0,075 \%$ & $\begin{array}{c}\text { Memenuhi } \\
\text { syarat }\end{array}$ \\
\hline
\end{tabular}

Alkali bebas dalam bentuk $\mathrm{K}_{2} \mathrm{O}$ merupakan alkali yang tidak diikat sebagai senyawa. Tujuan dari pengujian ini untuk mengukur kandungan alkali bebas yang terbentuk, hal ini penting karena alkali memiliki sifat yang keras dan dapat menyebabkan iritasi pada kulit (Rizky, 2013). Kadar maksimal alkali bebas yang ditetapkan SNI ialah $0,1 \%$. Hasil yang diperoleh menunjukan kadar alkali bebas berada kurang dari $0,1 \%$.

Tabel 7. Hasil uji bobot jenis

\begin{tabular}{ccc}
\hline Sediaan & $\begin{array}{c}\text { Bobot } \\
\text { jenis(gr/ml) }\end{array}$ & Keterangan \\
\hline Basis Sabun Cair & 1,018 & $\begin{array}{c}\text { Memenuhi } \\
\text { syarat }\end{array}$ \\
\hline $\begin{array}{c}\text { Sabun cair } \\
\text { konsentrasi 4\% }\end{array}$ & 1,014 & $\begin{array}{c}\text { Memenuhi } \\
\text { syarat }\end{array}$ \\
\hline $\begin{array}{c}\text { Sabun cair } \\
\text { konsentrasi 6\% }\end{array}$ & 1,033 & $\begin{array}{c}\text { Memenuhi } \\
\text { syarat }\end{array}$ \\
\hline $\begin{array}{c}\text { Sabun cair } \\
\text { konsentrasi 8\% }\end{array}$ & 1,047 & $\begin{array}{c}\text { Memenuhi } \\
\text { syarat }\end{array}$ \\
\hline $\begin{array}{c}\text { Sabun cair } \\
\text { konsentrasi 10\% }\end{array}$ & 1,015 & $\begin{array}{c}\text { Memenuhi } \\
\text { syarat }\end{array}$ \\
\hline $\begin{array}{c}\text { Sabun cair } \\
\text { konsentrasi 12\% }\end{array}$ & 1,035 & $\begin{array}{c}\text { Memenuhi } \\
\text { syarat }\end{array}$ \\
\hline
\end{tabular}

Pengujian bobot jenis bertujuan untuk menentukan mutu dan melihat kemurnian dari suatu senyawa, dalam hal ini khususnya sabun cair yang dihasilkan. Untuk bobot jenis sediaan sabun cair yang ditetapkan SNI berada diantara 1,011,10. Sedangkan hasil dari pengujian bobot jenis dari sediaan sabun cair berada diantara 1,018 sampai 1,035 , artinya sediaan sabun cair yang dibuat memenuhi standar yang ditetapkan oleh SNI. Nilai bobot jenis dipengaruhi oleh bahan penyusun dan sifat fisiknya. Menurut Gaman dan sherington (1990) penurunan bobot jenis disebabkan oleh adanya lemak atau etanol dalam larutan. 
Tabel 8. Hasil pengujian antijamur

\begin{tabular}{cccccc}
\hline & \multicolumn{7}{c}{ Hasil pengukuran diameter zona hambat (mm) } \\
\hline & Perlakuan 1 & Perlakuan 2 & Perlakuan 3 & Rata-rata & Keterangan \\
\hline $\mathrm{K}(-)$ & 1 & 1 & 2 & 1,3 & Lemah \\
\hline $\mathrm{K}(+)$ & 15 & 15 & 16 & 15,3 & Kuat \\
\hline $\mathrm{F} 1(4 \%)$ & 15 & 17 & 18 & 15,3 & Kuat \\
\hline $\mathrm{F} 2(6 \%)$ & 14 & 12 & 16 & 12,7 & Kuat \\
\hline $\mathrm{F} 3(8 \%)$ & 11 & 14 & 13 & 11,3 & Kuat \\
\hline $\mathrm{F} 4(10 \%)$ & 10 & 16 & 19 & 13,7 & Kuat \\
\hline F5 (12\%) & 17 & 10 & 21 & 14,7 & Kuat \\
\hline
\end{tabular}

Hasil dari pengujian antijamur dari sediaan sabun cair ektrak daun Turi menunjukkan bahwa semua sediaan memiliki zona bening dengan diameter lebih dari $10 \mathrm{~mm}$ dan kurang dari $20 \mathrm{~mm}$. Kriteria daya hambat antibakteri menurut Davis dan Stout (1971) dikategorikan berdasarkan diameter zona hambat yang terbentuk yaitu diameter zona hambat $5 \mathrm{~mm}$ atau kurang dikategorikan lemah, zona hambat $5-10 \mathrm{~mm}$ dikategorikan sedang, zona hambat $10-20 \mathrm{~mm}$ dikategorikan kuat dan zona hambat $20 \mathrm{~mm}$ atau lebih dikategorikan sangat kuat. Dengan begitu maka dapat dikatakan bahwa sediaan sabun cair ekstrak daun Turi memiliki kategori yang kuat dalam membunuh jamur Candida albicans.

Dalam hasil penelitian menunjukan bahwa diameter zona hambat yang paling kuat adalah sabun cair ekstrak daun turi dengan konsentrasi 4\%. Dimana jika merujuk pada kadar flavonoid, saponin dan tannin sebagai zat antijamur, seharusnya semakin tinggi konsentrasi maka semakin tinggi pula daya hambat yang seharusnya dihasilkan. Hal ini disebabkan karena semakin tinggi konsentrasi membuat tingkat kelarutan menurun sehingga zat aktif tidak dapat berdifusi ke dalam agar sehingga didapatkan hasil daya hambat yang berkurang (Putra et al, 2015).

Data penelitian diameter zona daya hambat yang didapatkan kemudian dilakukan uji statistik dengan metode One Way Anova menggunakan aplikasi SPSS versi 26. Sebelum dilakukan pengujian One Way Anova data hasil penelitian harus dilakukan uji Normalitas dan uji Homogenitas sebagai syarat untuk dilakukan uji One Way Anova. Hasil dari uji Normalitas menunjukan bahwa rata-rata data menunjukan nilai signifikansi $>0,05$ yang artinya bahwa data

tersebut terdistribusi normal. Selanjutnya dilakukan uji Homogenitas dan hasilnya menunjukan nilai signifikansi $<0,05$ yang artinya data tersebut tidak homogen. Menurut Uyanto (2009), apabila data yang terdistribusi normal dan tidak homogen, maka dilakukan uji BrownForsythe. Data yang dihasilkan dari uji BrownForsythe menunjukan nilai signifikansi 0,139>0,05 yang dapat diartikan data tersebut homogen. Kemudian hasil dari uji One Way Anova menunjukan nilai signifikansi $<0,05$ sehingga $\mathrm{H}_{0}$ ditolak dan terima $\mathrm{H}_{1}$. Maka terdapat perbedaan kekuatan daya hambat antijamur terhadap jamur Candida albicans antara sediaan sabun cair ekstrak etanol daun Turi pada konsentrasi 4\%, 6\%, 8\%, 10\% dan 12\% dengan basis sabun cair dan Betadin SC.

Penyebab dari sediaan sabun cair ekstrak daun Turi memiliki kemampuan untuk membunuh mikroorganisme karena daun Turi mengandung saponin, flavonoid dan tannin yang dapat berperan sebagai anti-mikroorganisme. Flavonoid dan saponin dapat mengakibatkan denaturasi protein sehingga meningkatkan permeabilitas membran sel. Denaturasi protein menyebabkan gangguan dalam pembentukan sel sehingga mengubah komposisi protein (Wahyuningtias, 2008). Sedangkan mekanisme penghambatan tannin yaitu dengan cara dinding sel yang sebelumnya telah mengalami lisis yang diakibatkan oleh flavonoid dan saponin, sehingga menyebabkan senyawa tannin dapat dengan mudah masuk kedalam sel dan mengkoagulase protoplasma sel mikroorganisme (Masduki, 1996). 
Selain sediaan sabun cari ekstrak daun Turi yang memiliki zona hambat, ternyata basis sabun cair memiliki zona hambat dengan diameter rata-rata $1,3 \mathrm{~mm}$ dan dikategorikan lemah. Penyebabnya diduga karena dalam pembuatan sabun cair itu menggunakan minyak zaitun sebagai asam lemaknya. Minyak zaitun mengandung fenolik dan vitamin E. Menurut Guenther (1987), senyawa fenolik aktif bersifat sebagai antimikroorganisme dengan mekanisme membentuk kompleks dengan protein sel sehingga menghambat kerja enzim pada mikroorganisme.

\section{KESIMPULAN}

Berdasarkan hasil penelitian maka dapat disimpulkan bahwa, ekstrak etanol daun Turi (Sesbania grandiflora L.) dapat diformulasikan menjadi sediaan sabun cair dengan konsentrasi $4 \%$, $6 \%, 8 \%, 10 \%$ dan $12 \%$. Dengan hasil pengujian mutu sediaan sabun cair ekstrak etanol daun Turi (Sesbania grandiflora L.) memenuhi standar yang ditetapkan oleh SNI pada pengujian organoleptik, uji pH, uji tinggi, uji kadar air, uji alkali bebas dan uji bobot jenis. Berdasarkan pengujian antijamur sediaan sabun cair ektrak etanol daun Turi (Sesbania grandiflora L.) terhadap jamur Candida albicans didapatkan hasil semua sediaan memiliki daya hambat terhadap jamur dan dikategorikan kuat.

\section{SARAN}

Disarankan untuk penelitian lebih lanjut untuk melakukan pengujian yang belum dilakukan yaitu uji viskositas dan uji asam lemak bebas. Untuk mendapat produk yang lebih disukai masyarakat, sebaiknya sediaan sabun cair menghilangkan warna dan bau dari ekstrak.

\section{DAFTAR PUSTAKA}

Astriani. 2011. Uji Aktivitas Antimikroba Ekstrak Daun Turi (Sesbania grandiflora L.) Secara KLT-Bioautografi. [skripsi]. Fakultas Ilmu Kesehatan Universitas Islam Negri Alauddin, Makassar.
Davis, W.W. dan Stout, TR. 1971. Disc Plate Methods of Microbiological Antibiotic Assay. Microbiology.

Farizal, J. dan Dewa, E. A. R. S. 2017. Identifikasi Candida albicans pada Saliva Wanita Penderita Diabetes Melitus. Jurnal Teknologi Laboratorium. 6(2):67-74.

Frost, P., dan Horowitz, S. 1982. Principals of Cosmetics for the Dermatologist. C.V Mosby Co. England.

Gaman, P. M. dan Sherrington. 1994. Ilmu Pangan, Nutrisi dan Mikrobiologi Edisi 2. Gadjah Mada University Press, Yogyakarta.

Guenther, E. 1987. Minyak Atsiri Jilid I. Penerbit Universitas Indonesia, Jakarta.

Syamsuhidayat, S. S. dan Hutapea, J. R. 1991. Inventaris Tanaman Obat Indonesia. Departemen Kesehatan RI Badan Penelitian dan Pengembangan Kesehatan, Batu.

Masduki, I. 1996. Uji Efek Antibakteri Ekstrak Biji Pinang (Areca catechu) terhadap $S$. aureus dan E. coli secara in vitro. Jurnal Cermin Dunia Kedokteran. 104: 21-29.

Mutmainah, dan Franyoto, Y. D. 2015. Formulasi dan Evaluasi Sabun Cair Ekstrak Etanol Jahe Merah (Zingiber officinale var Rubrum) Serta Uji Aktivitasnya Sebagai Antikeputihan. Jurnal Ilmu Farmasi \& Farmasi Klinik. 12(1): 1-7.

Putra, Ikhsan, A., Erly dan Machdawaty, M. 2015. Uji Efek Antibakteri Ekstrak Etanol Kulit Batang Salam (Syzigium polyanthum (Wight) Walp) terhadap Staphylococcus aureus dan Escherichia coli secara invitro. Jurnal Kesehatan Andalas. 4(2): 497-501.

Ratna, St., Rahim, A. R. dan Hasyim, H. 2018. Aktivitas Antimikroba Ekstrak Daun Turi Putih (Sesbania grandiflora L.) Terhadap Pertumbuhan Candida albicans dan Staphylococcus aureus. Jurnal Media Farmasi. 14(1): 17-21.

Rizky, D. N. 2013. Penetapan Kadar Alkali Bebas Pada Sabun Mandi Sediaan Padat Secara 
Titrimetri. [skripsi]. Universitas Sumatra Utara, Medan.

SNI. 1996. Sabun Mandi Cair. SNI 06-4085-1996. Dewan Standarisasi Nasional, Jakarta.

SNI. 2017. Sabun Mandi Cair. SNI 4084-2017. Badan Standarisasi Nasional, Jakarta.

Susanti, G. 2016. Aktivitas Senyawa Antibakteri Infusa Daun Turi Terhadap Bakteri Bacillus Subtillis dan Escherichia coli secara in vitro. [skripsi]. Program Studi Farmasi Sekolah Tinggi Ilmu Kesehatan Ngudi Waluyo Ungaran, Semarang.

Uyanto, S. S. 2009. Pedoman Analisis dengan SPSS. Graha Ilmu, Yogyakarta.

Wahyuningtyas, E. 2008. Pengaruh Ekstrak Graptophyllum pictum terhadap Pertumbuhan Candida albicans pada Plat Gigi Tiruan Resin Akrilik. Indonesian Journal of Dentistry, 15(3):187- 191. 